\title{
Audience Perception of Effective Communication in Nigerian Paintings
}

\author{
Johnson Adelani Abodunrin \\ Department of Fine and Applied Arts, Ladoke Akintola University of Technology, \\ Ogbomoso, Nigeria \\ ${ }^{\square}$ E-mail: jaabodunrin@lautech.edu.ng
}

Received: November 12, 2016. Revised: December 10, 2016. Accepted: December 25, 2016

\begin{abstract}
Artists in Nigeria perceived effective communication differently irrespective of the socio-economic status.Communication effectiveness depends largely on the understanding of the message being passed between a sender and a receiver. Painting has been used over time to express emotion and feeling to the perceiving audience. The study is audience's perception of communication in Nigeria painting and how it varies with the socio-economic characteristics such as age, education, gender, and being professional artist or art lovers. Questionnaires were distributed and administered to examine how the status of the art audience makes or mars effective communication in painting. The inferential statistics that were employed include "chi-square test" to test the relationship between different variables. The data were taken in ordinal form using Likert's scale, and transformed into interval data. This was done by attaching statistical weights to the responses in the order of importance which were summed up for the parametric testing. Findings show that gender factor has nothing to do with the understanding of paintings. Also, the level of education obtained by the audience does not have much to do with understanding of contemporary Nigerian painting but a better exposure to the issue concerning the stylistic development of Nigerian painting. Art practitioners must adequately be guided on stylistic trend in painting, art education should be more intensified in educational curriculum in Nigeria. The paper concludes that audience requires a better exposure to the issues concerning the stylistic development of Nigerian painting for effective communication to take place.
\end{abstract}

Keywords: audience perception; communication; painting; Nigeria

How to Cite: Abodunrin, J. A. (2016). Audience Perception of Effective Communication in Nigerian Paintings. Harmonia: Journal of Arts Research and Education, 16(2), 103-115. doi:http:/ /dx.doi.org/10.15294/harmonia.v16i2.7824

\section{INTRODUCTION}

Perception is the ability or consciousness of understanding something through vision, taste, smell, feelings and hearing. Also, it is a high-order function that deals with more complex characteristics. Audience uses prior knowledge and experience to interpret and create meaning from what they see, taste, smell, feel or hear. Audiences have an innate ability to establish order according to certain laws of perception, such as Gestalt psychology (Harrigan,
2007).

At the beginning of the twentieth century, the school of Gestalt psychology emerged in Germany as a reaction to structuralism, another school of thought (Encyclopedia Britannica, 2014). The Gestalt school of thought believed that perception is the result of the relation between stimuli, rather than the existence of the stimuli themselves. The word Gestalt means 'form', 'shape', or 'whole configuration' in German.There are different levels and aspects of perception, but however inex- 
perienced an artist or audience is, it is impossible to paint without some awareness of the basic elements such as colour and shape. There is an important set of visual properties that are called 'pre-attentive attributes' of visual perception. They are pre-attentive in that the process of perceiving them does not involve conscious thought; it is automatic and immediate. This includes properties such as elements and principles of design.

Visual perception is a function of our eyes and brain. We see images as a whole rather than in parts. However, images can be broken down into their visual elements: line, shape, texture, and color. This element allows the eye to see images of representation with the assistance of the human brain to decode them. Seeing objects of Art allow us to perceive the meaning of the expression. Audience perception of an object depends largely on the reaction of the eye been adequately sensed by the brain for effective communication to take place. Communication and perception are two inseparable concepts when it comes to the issue of meaning and interpretation of an object. The way one audience perceives effective communication might be different from the other, thereby creating a multidimensional approach to the perception of an artwork.

Communication as a means of relaying information is as old as creation itself. It is notably characterized by diverse languages, both verbal and non-verbal. However, as important as language is in the day to day activities of man, and to the humanity of man, its origin was difficult to locate both in time and space (Babajide 2000, p. 1). Consequently, language can be viewed as the use of words or signs in an agreed way as the method of communication, among a particular group of people or creed (Barber 1964, p. 15). Communication also exists among different groups of animals, which is the transfer of information on the part of one or more animals that has an effect on the current or future behaviour of another animal (Tracii, 2010, p. 25). The study of this sometimes called zoosemiotics (defined as the study of sign communication, or semiosis in animals; distinguishable from anthroposemiotics, the study of human communication). Communication has been associated with all living beings from the very beginning. There are many complex feelings which cannot be expressed through verbal means so people all over the word, use arts, particularly painting to express individual experiences and creativity. In this study, effective communication is contextualized, when an expression of visuals is direct, unambiguous, informative and meaningful to people irrespective of social and educational background.

Painting as a form of communication is an integral part of visual art studies. Through painting much is expressed without making a verbal statement. The artists symbolize the intended messages, codify them and allow the audience to decode and interpret the hidden messages or meanings. Therefore, painting is not only a tool of recorded human history, but also a tool for conveying a wide range of stories, emotions, feelings, inner world symbolically, didactically or in a hidden mode. Existing studies have shown that communication is relatively significant to human existence (Oyewo, 2000, p. 77-78; Lamidi, 2000, p. 86; Adeniji, 2004, p. 64). Specifically, Oladosu (2000, p. 1) reveals that the history of human development projects communication as the main vehicle exploited to meet life expectation and upon which it gain complete dominance of the immediate environment.

Communication through visual arts has been extensively explored by various scholars, especially in the area of drawing, graphic design and photography. Among such scholars are Cleaver (1966), Hill (1966), Igboanugo (1976), Kalilu (1999), Folorunso (2001), Getlein (2002), Davidson (2003), and Woods (2011). Their works concentrated more on drawing as an instrument of visual communication rather than painting. However, painting differs from drawing with respect to nature, types, and materials. Painting is characterized by colour and design and they 
are of different types which include oil on canvas, watercolour, acrylic, and mixed media. The material use in painting also makes a significant difference. However, no specific attentions have been paid to audience perception of effective communication in contemporary Nigerian painting, an obvious gap thus filled by this study.

\section{METHOD}

Audience's perceptions of contemporary Nigerian painting were analyzed to determine how styles, subject matter and media and how it contributed to the effective communication in Nigerian painting. This study utilizes ordinal data using Likert's scale, which ranges between 1 and 5 for strongly disagree (1), disagree (2) uncertain (3), agree (4) and strongly agree (5) respectively. This was aggregated for all the respondents by computing the averages, which also range between 1 and 5 as for the individuals above. This was done by attaching statistical weights to the responses in order of importance. These weights were summed up and were subjected to descriptive statistics of mean and tabulation. Respondents' assessments of different aspects of audience's perceptions of contemporary Nigerian painting were based on eighteen variables which are broadly divided into three, namely style; media and subject matter.

This study is limited to analysis of paintings in Nigeria by Nigerian artists. There are several categories of artists in Nigeria. The paintings that were studied in this work were produced by professional painters from diverse tertiary institutions and geographical background in Nigeria, who have also distinguished themselves through practices and exhibition over the years both at home and abroad. The study covers the period from 1970 to 2010 (a period of forty years). The media in painting that the study concentrated on are: oil paint, watercolor, gouache, acrylic, pen and ink, pastel, ink and brush, beads and mixed media.

The perception of the audience was measured based on the variables, emanated from Table 2 this includes style, subject matter, and media which enables effective communication and meaning in painting. The research question addresses how the audience understands the symbolic meaning and emotions of painting in Nigeria. The study was carried out in Lagos state, Nigeria. Lagos is the major commercial hub of Nigeria, where most of these art stakeholders reside were targeted as the sample frame for proper and comprehensive examination. Lagos State has evolved to be considered as the most urbanized and economic nerve center in Nigeria (Odumosu, 1999, p. 1). Furthermore, questionnaires were randomly distributed based on the geographical spread and training of the respondents (Table 1). The questionnaires were randomly distributed to graduate from various art schools, both in the teaching profession and professional practice. A total number of 350 questionnaires were distributed out of which 287 were returned for analysis. Therefore, 115 questionnaires $(40.1 \%)$ were retrieved from artists, who combine teaching and practice, this is necessary because they constitute a larger population among the respondents. Full-time professional Artists returned 86 questionnaires $(29.9 \%)$, and this could be attributed to the instability in terms of location of various professional artists, while 29 questionnaires $(10.1 \%)$ were received from 37 registered gallery owners in Lagos State (Directories of galleries in Lagos). However, 57 (19.9\%) questionnaires were retrieved from Art lovers. The selection of this category was based on those who collect paintings both in private and public sectors in Nigeria. As indicated in Table 1 below. The data obtained from the questionnaires were then analyzed to determine perceptions of effective communication in painting.

In order to achieve the objective of this study, the respondents were categorized into two: professional artists who are in full-time studio practice and those that are combining practice and academics. 
Table 1. Questionnaire Distribution (\%)

\begin{tabular}{ccc}
\hline Audience & Frequency & Percentage \\
\hline Professional Artist & 86 & 29.9 \\
Teaching/Practice & 115 & 40.1 \\
Gallery owners & 29 & 10.1 \\
Art lovers/ & 57 & 19.9 \\
audience & & \\
\hline
\end{tabular}

Chart 1. Questionnaire distribution in the study area

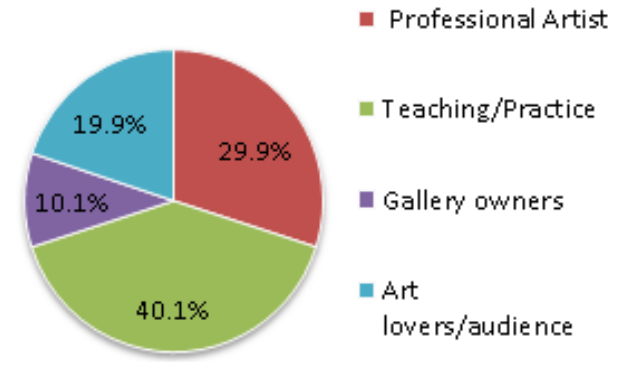

\section{RESULT AND DISCUSSION}

The results of chi-square test for a relationship between socio-economic characteristics and audience perception revealed that a significant relationship was found between education level and audience perception of painting being an aspect of nonverbal communication as one of the best forms of communication and audience understanding of painting in terms of forms and colours as the primary contestant $\left(X^{2}=\right.$ 22.30, $P=0.034)\left(X^{2}=33.70, P=0.01\right)$ respectively.

Also, a significant relationship was found between the age and the way $\mathrm{Ni}$ gerians perceive colour symbolisms as means of communication. $\left(\mathrm{X}^{2}=34.53, \mathrm{P}=\right.$ $0.01)$. In addition, age is also a significant factor to how symbolic and thematic characteristics of Nigerian paintings are well understood $\left(X^{2}=9.63, P=0.65\right)$ and the exposure of students (apprentice) to the relevance of communication in painting $\left(\mathrm{X}^{2}=\right.$ $9.63, \mathrm{P}=0.65)$. It is also revealed from the results of the finding that the descriptive details or title of all Nigerian paintings and the apprenticeship methods of training are influenced by age $\left(X^{2}=26.65, P=0.013\right)\left(X^{2}\right.$ $=31.67, \mathrm{P}=0.00)$ while the pictorial expression in the mind of the viewers and the ex- pression of paintings to collage, mixed media and others are also influenced by age $\left(X^{2}=14.32, P=0.28\right)\left(X^{2}=47.28, P=0.00\right)$. The results of findings in table 3 revealed that the audience perception is not influenced by gender or whether a professional or an art lover.

This study utilizes ordinal data using Likert's scale, which ranges between 1 and 5 for strongly disagree (1), disagree (2) uncertain (3), agree (4) and strongly agree (5) respectively.

This shows that gender as a factor does not affect the effectiveness of communication, that is, the transmission of emotional feelings of the artist through painting to the perceiving audience is not influenced by their gender. That is, the Female audience can equally understand the content of contemporary Nigeria paintings as their male counterpart. The responses when compared among male and female respondents are not significantly different. This implies that they perceive effective communication in the same manner; aside the fact that the percentage of male respondents are higher compared to the female respondents.

It was revealed from the findings of the study that there is a need to improve with the development of art education in Nigeria so that the appreciable understanding of painting forms could be better understood. Also, knowledge about perception and understanding of the content of painting does not have gender affiliation for effective communication to take place and practitioners in the field of art must adequately be guided or informed on stylistic trend in contemporary Nigerian painting irrespective of the age difference, so that the confusing nature of the content of painting would be clarified.Also, the level of education obtained by the audience does not have much to do with understanding of contemporary Nigerian painting but a better exposure to the issue concerning the stylistic development of Nigerian painting

Table 2 reveals that the respondents with university education spoke more af- 
Table 2. Distribution of Respondents by educational levels

\begin{tabular}{|c|c|c|c|c|c|c|c|c|c|c|}
\hline $\mathrm{S} / \mathrm{N}$ & VARIABLES & UNI & POLY & NCE & SEC & Total & Average & $X^{2}$ & P-Value & Remark \\
\hline 1 & $\begin{array}{l}\text { All Nigerian paintings } \\
\text { are effective in terms } \\
\text { of communication }\end{array}$ & 536 & 151 & 09 & 60 & 756 & 2.6 & 16.2 & 0.184 & $\begin{array}{l}\text { Differ- } \\
\text { ence not } \\
\text { signifi- } \\
\text { cant }\end{array}$ \\
\hline 2 & $\begin{array}{l}\text { Painting as an aspect } \\
\text { of non-verbal commu- } \\
\text { nication is one of the } \\
\text { best forms of commu- } \\
\text { nication }\end{array}$ & 656 & 147 & 14 & 61 & 878 & 3.0 & 22.3 & 0.034 & $\begin{array}{l}\text { Signifi- } \\
\text { cant }\end{array}$ \\
\hline 3 & $\begin{array}{l}\text { Nigerian are strongly } \\
\text { aware of colour sym- } \\
\text { bolism as means of } \\
\text { communications }\end{array}$ & 537 & 120 & 08 & 58 & 723 & 2.5 & 14.9 & 0.247 & $\begin{array}{l}\text { Differ- } \\
\text { ence not } \\
\text { signifi- } \\
\text { cant }\end{array}$ \\
\hline 4 & $\begin{array}{l}\text { Audience in Nigeria } \\
\text { are all aware of and } \\
\text { look at painting }\end{array}$ & 506 & 123 & 09 & 44 & 682 & 2.3 & 11.4 & 0.493 & $\begin{array}{l}\text { Differ- } \\
\text { ence not } \\
\text { signifi- } \\
\text { cant }\end{array}$ \\
\hline 5 & $\begin{array}{l}\text { All artistic spectators } \\
\text { can decode the content } \\
\text { of painting }\end{array}$ & 347 & 101 & 11 & 58 & 517 & 1.8 & 14.2 & 0.290 & $\begin{array}{l}\text { Differ- } \\
\text { ence not } \\
\text { signifi- } \\
\text { cant }\end{array}$ \\
\hline 6 & $\begin{array}{l}\text { Communication is } \\
\text { one of the functions of } \\
\text { Nigerian painting }\end{array}$ & 674 & 145 & 12 & 63 & 894 & 3.1 & 13.6 & 0.339 & $\begin{array}{l}\text { Differ- } \\
\text { ence not } \\
\text { signifi- } \\
\text { cant }\end{array}$ \\
\hline 7 & $\begin{array}{l}\text { Paintings that are } \\
\text { produced from 1970till } \\
\text { date are expressive }\end{array}$ & 589 & 125 & 12 & 55 & 781 & 2.7 & 11.2 & 0.514 & $\begin{array}{l}\text { Differ- } \\
\text { ence not } \\
\text { signifi- } \\
\text { cant }\end{array}$ \\
\hline 8 & $\begin{array}{l}\text { Stylistic and thematic } \\
\text { characteristics of Nige- } \\
\text { rian painting are well } \\
\text { understood }\end{array}$ & 515 & 119 & 14 & 50 & 698 & 2.4 & 20.6 & 0.056 & $\begin{array}{l}\text { Differ- } \\
\text { ence not } \\
\text { signifi- } \\
\text { cant }\end{array}$ \\
\hline 9 & $\begin{array}{l}\text { Painting expressed in } \\
\text { realism or naturalism } \\
\text { styles are clearer in } \\
\text { content and meaning }\end{array}$ & 654 & 146 & 13 & 67 & 880 & 3.0 & 8.2 & 0.770 & $\begin{array}{l}\text { Differ- } \\
\text { ence not } \\
\text { signifi- } \\
\text { cant }\end{array}$ \\
\hline 10 & $\begin{array}{l}\text { Student / apprentices } \\
\text { are adequately ex- } \\
\text { posed to the relevance } \\
\text { of communication in } \\
\text { painting. }\end{array}$ & 572 & 123 & 12 & 15 & 757 & 2.6 & 15.6 & 0.211 & $\begin{array}{l}\text { Differ- } \\
\text { ence not } \\
\text { signifi- } \\
\text { cant }\end{array}$ \\
\hline 11 & $\begin{array}{l}\text { All Nigerian painting } \\
\text { should have descrip- } \\
\text { tive details or title }\end{array}$ & 660 & 145 & 16 & 71 & 892 & 3.1 & 11.7 & 0.472 & $\begin{array}{l}\text { Differ- } \\
\text { ence not } \\
\text { signifi- } \\
\text { cant }\end{array}$ \\
\hline 12 & $\begin{array}{l}\text { The apprenticeship } \\
\text { method of training in } \\
\text { art appears to be lost }\end{array}$ & 490 & 114 & 08 & 57 & 617 & 2.1 & 10.8 & 0.597 & $\begin{array}{l}\text { Differ- } \\
\text { ence not } \\
\text { signifi- } \\
\text { cant }\end{array}$ \\
\hline 13 & $\begin{array}{l}\text { The individuality } \\
\text { and identity issue in } \\
\text { contemporary Nige- } \\
\text { rian painting seems to } \\
\text { bring clarity of expres- } \\
\text { sion. }\end{array}$ & 560 & 129 & 10 & 55 & 754 & 2.6 & 9.7 & 0.692 & $\begin{array}{l}\text { Differ- } \\
\text { ence not } \\
\text { signifi- } \\
\text { cant }\end{array}$ \\
\hline
\end{tabular}




\begin{tabular}{|c|c|c|c|c|c|c|c|c|c|c|}
\hline 14 & $\begin{array}{l}\text { Paintingconstitutes } \\
\text { a veritable bridge } \\
\text { between the inner and } \\
\text { outer worlds of man }\end{array}$ & 649 & 138 & 12 & 62 & 861 & 3.0 & 20.9 & 0.052 & $\begin{array}{l}\text { Differ- } \\
\text { ence not } \\
\text { signifi- } \\
\text { cant }\end{array}$ \\
\hline 15 & $\begin{array}{l}\text { A picture has a better } \\
\text { and lasting impres- } \\
\text { sion in the mind of } \\
\text { the viewer than verbal } \\
\text { aids. }\end{array}$ & 722 & 140 & 13 & 64 & 939 & 3.2 & 20.0 & 0.068 & $\begin{array}{l}\text { Differ- } \\
\text { ence not } \\
\text { signifi- } \\
\text { cant }\end{array}$ \\
\hline 16 & $\begin{array}{l}\text { Everybody is quite } \\
\text { aware of painting as } \\
\text { an aspect of art. }\end{array}$ & 670 & 141 & 12 & 67 & 890 & 3.1 & 18.0 & 0.117 & $\begin{array}{l}\text { Differ- } \\
\text { ence not } \\
\text { signifi- } \\
\text { cant }\end{array}$ \\
\hline 17 & $\begin{array}{l}\text { People have the } \\
\text { understanding of } \\
\text { painting in terms of } \\
\text { forms and colours as } \\
\text { the primary content. }\end{array}$ & 620 & 114 & 7 & 70 & 811 & 2.8 & 33.7 & 0.001 & $\begin{array}{l}\text { signifi- } \\
\text { cant }\end{array}$ \\
\hline 18 & $\begin{array}{l}\text { Paintings done in } \\
\text { college, mixed media } \\
\text { abstraction, mono- } \\
\text { media styles, realistic } \\
\text { styles are well known } \\
\text { to everybody. }\end{array}$ & 441 & 71 & 4 & 47 & 563 & 1.9 & 12.61 & 0.398 & $\begin{array}{l}\text { Differ- } \\
\text { ence not } \\
\text { signifi- } \\
\text { cant }\end{array}$ \\
\hline
\end{tabular}

Table 3. Distribution of Respondents by Gender

\begin{tabular}{|c|c|c|c|c|c|c|c|c|}
\hline $\mathrm{S} / \mathrm{N}$ & VARIABLES & MALE & FEMALE & TOTAL & AVERAGE & $X^{2}$ & P-VALUE & REMARK \\
\hline 1 & $\begin{array}{l}\text { All Nigerian paint- } \\
\text { ings are effective in } \\
\text { terms of communica- } \\
\text { tion }\end{array}$ & 556 & 296 & 852 & 3.0 & 1.863 & 0.761 & $\begin{array}{l}\text { Difference } \\
\text { not Signifi- } \\
\quad \text { cant }\end{array}$ \\
\hline 2 & $\begin{array}{l}\text { Painting as an aspect } \\
\text { of non-verbal com- } \\
\text { munication is one } \\
\text { of the best forms of } \\
\text { communication }\end{array}$ & 572 & 306 & 878 & 3.1 & 3.320 & 0.506 & $\begin{array}{l}\text { Difference } \\
\text { not Signifi- } \\
\text { cant }\end{array}$ \\
\hline 3 & $\begin{array}{l}\text { Nigerian are strongly } \\
\text { aware of colour sym- } \\
\text { bolism as means of } \\
\text { communications }\end{array}$ & 472 & 261 & 733 & 1.6 & 2.859 & 0.582 & $\begin{array}{l}\text { Difference } \\
\text { not Signifi- } \\
\text { cant }\end{array}$ \\
\hline 4 & $\begin{array}{l}\text { Audience in Nigeria } \\
\text { are all aware of and } \\
\text { look at painting }\end{array}$ & 441 & 241 & 682 & 2.4 & 6.002 & 0.199 & $\begin{array}{l}\text { Difference } \\
\text { not Signifi- } \\
\quad \text { cant }\end{array}$ \\
\hline 5 & $\begin{array}{l}\text { All artistic specta- } \\
\text { tors can decode the } \\
\text { content of painting }\end{array}$ & 407 & 215 & 622 & 2.2 & 3.879 & 0.423 & $\begin{array}{l}\text { Difference } \\
\text { not Signifi- } \\
\text { cant }\end{array}$ \\
\hline 6 & $\begin{array}{l}\text { Communication is } \\
\text { one of the functions } \\
\text { of Nigerian painting }\end{array}$ & 602 & 292 & 894 & 3.1 & 3.339 & 0.503 & $\begin{array}{l}\text { Difference } \\
\text { not Signifi- } \\
\quad \text { cant }\end{array}$ \\
\hline 7 & $\begin{array}{l}\text { Paintings that are } \\
\text { produced from } \\
\text { 1970till date are } \\
\text { expressive }\end{array}$ & 525 & 256 & 781 & 2.7 & 5.641 & 0.228 & $\begin{array}{l}\text { Difference } \\
\text { not Signifi- } \\
\text { cant }\end{array}$ \\
\hline
\end{tabular}




\begin{tabular}{|c|c|c|c|c|c|c|c|c|}
\hline 8 & $\begin{array}{l}\text { Stylistic and thematic } \\
\text { characteristics of Ni- } \\
\text { gerian painting are } \\
\text { well understood }\end{array}$ & 457 & 239 & 698 & 2.4 & 5.455 & 0.244 & $\begin{array}{c}\text { Difference } \\
\text { not } \\
\text { Significant }\end{array}$ \\
\hline 9 & $\begin{array}{l}\text { Painting expressed in } \\
\text { realism or naturalism } \\
\text { styles are clearer in } \\
\text { content and meaning }\end{array}$ & 588 & 292 & 880 & 3.1 & 3.275 & 0.513 & $\begin{array}{l}\text { Difference } \\
\text { not } \\
\text { Significant }\end{array}$ \\
\hline 10 & $\begin{array}{l}\text { Student / appren- } \\
\text { tices are adequately } \\
\text { exposed to the } \\
\text { relevance of commu- } \\
\text { nication in painting. }\end{array}$ & 491 & 274 & 765 & 2.7 & 6.806 & 0.146 & $\begin{array}{l}\text { Difference } \\
\text { not } \\
\text { Significant }\end{array}$ \\
\hline 11 & $\begin{array}{l}\text { All Nigerian painting } \\
\text { should have descrip- } \\
\text { tive details or title }\end{array}$ & 587 & 305 & 892 & 3.1 & 4.349 & 0.361 & $\begin{array}{c}\text { Difference } \\
\text { not } \\
\text { Significant }\end{array}$ \\
\hline 12 & $\begin{array}{l}\text { The apprenticeship } \\
\text { method of training in } \\
\text { art appears to be lost }\end{array}$ & 433 & 236 & 669 & 2.3 & 9.334 & 0.053 & $\begin{array}{l}\text { Difference } \\
\text { not } \\
\text { Significant }\end{array}$ \\
\hline 13 & $\begin{array}{l}\text { The individuality } \\
\text { and identity issue } \\
\text { in contemporary } \\
\text { Nigerian painting } \\
\text { seems to bring clarity } \\
\text { of expression. }\end{array}$ & 517 & 243 & 760 & 2.6 & 6.624 & 0.157 & $\begin{array}{l}\text { Difference } \\
\text { not } \\
\text { Significant }\end{array}$ \\
\hline 14 & $\begin{array}{l}\text { Paintingconstitutes } \\
\text { a veritable bridge } \\
\text { between the inner } \\
\text { and outer worlds of } \\
\text { man }\end{array}$ & 580 & 281 & 861 & 3.0 & 7.222 & 0.125 & $\begin{array}{l}\text { Difference } \\
\text { not } \\
\text { Significant }\end{array}$ \\
\hline 15 & $\begin{array}{l}\text { A picture has a better } \\
\text { and lasting impres- } \\
\text { sion in the mind } \\
\text { of the viewer than } \\
\text { verbal aids. }\end{array}$ & 617 & 322 & 939 & 3.3 & 3.526 & 0.474 & $\begin{array}{l}\text { Difference } \\
\text { not } \\
\text { Significant }\end{array}$ \\
\hline 16 & $\begin{array}{l}\text { Everybody is quite } \\
\text { aware of painting as } \\
\text { an aspect of art. }\end{array}$ & 595 & 297 & 892 & 3.1 & 5.526 & 0.249 & $\begin{array}{l}\text { Difference } \\
\text { not } \\
\text { Significant }\end{array}$ \\
\hline 17 & $\begin{array}{l}\text { People have the } \\
\text { understanding of } \\
\text { painting in terms of } \\
\text { forms and colours as } \\
\text { the primary content. }\end{array}$ & 545 & 266 & 811 & 2.8 & 3.418 & 0.490 & $\begin{array}{l}\text { Difference } \\
\text { not } \\
\text { Significant }\end{array}$ \\
\hline 18 & $\begin{array}{l}\text { Paintings done in } \\
\text { collage, mixed media } \\
\text { abstraction, mono- } \\
\text { media styles, real- } \\
\text { istic styles are well } \\
\text { known to everybody. }\end{array}$ & 356 & 217 & 573 & 2.0 & 8.507 & 0.075 & $\begin{array}{l}\text { Difference } \\
\text { not } \\
\text { Significant }\end{array}$ \\
\hline
\end{tabular}


Table 4. Distribution of Respondents by professional artist and art lover

\begin{tabular}{|c|c|c|c|c|c|c|c|c|}
\hline $\mathrm{S} / \mathrm{N}$ & VARIABLES & $\begin{array}{l}\text { PROFES- } \\
\text { SIONAL } \\
\text { ARTIST }\end{array}$ & $\begin{array}{l}\text { ART } \\
\text { LOV- } \\
\text { ER }\end{array}$ & $\begin{array}{l}\text { TO- } \\
\text { TAL }\end{array}$ & $\begin{array}{l}\text { AV- } \\
\text { ER- } \\
\text { AGE }\end{array}$ & $X^{2}$ & $\begin{array}{c}\text { P- } \\
\text { VAL- } \\
\text { UE }\end{array}$ & REMARK \\
\hline 1 & $\begin{array}{l}\text { All Nigerian paintings are effec- } \\
\text { tive in terms of communication }\end{array}$ & 317 & 536 & 853 & 3.0 & 2.265 & 0.687 & $\begin{array}{l}\text { Difference not } \\
\text { Significant }\end{array}$ \\
\hline 2 & $\begin{array}{l}\text { Painting as an aspect of non-ver- } \\
\text { bal communication is one of the } \\
\text { best forms of communication }\end{array}$ & 354 & 524 & 878 & 3.1 & 13.170 & 0.010 & $\begin{array}{l}\text { Difference not } \\
\text { Significant }\end{array}$ \\
\hline 3 & $\begin{array}{l}\text { Nigerian are strongly aware of } \\
\text { colour symbolism as means of } \\
\text { communications }\end{array}$ & 262 & 461 & 723 & 2.5 & 7.371 & 0.118 & $\begin{array}{c}\text { Difference not } \\
\text { Significant }\end{array}$ \\
\hline 4 & $\begin{array}{l}\text { Audience in Nigeria are all } \\
\text { aware of and look at painting }\end{array}$ & 258 & 424 & 682 & 2.4 & 8.237 & 0.083 & $\begin{array}{l}\text { Difference not } \\
\text { Significant }\end{array}$ \\
\hline 5 & $\begin{array}{l}\text { All artistic spectators can decode } \\
\text { the content of painting }\end{array}$ & 231 & 391 & 622 & 2.2 & 18.552 & 0.001 & $\begin{array}{l}\text { Difference not } \\
\text { Significant }\end{array}$ \\
\hline 6 & $\begin{array}{l}\text { Communication is one of the } \\
\text { functions of Nigerian painting }\end{array}$ & 367 & 527 & 894 & 3.1 & 7.587 & 0.108 & $\begin{array}{l}\text { Difference not } \\
\text { Significant }\end{array}$ \\
\hline 7 & $\begin{array}{l}\text { Paintings that are produced } \\
\text { from 1970till date are expressive }\end{array}$ & 302 & 479 & 781 & 2.7 & 5.031 & 0.284 & $\begin{array}{l}\text { Difference not } \\
\text { Significant }\end{array}$ \\
\hline 8 & $\begin{array}{l}\text { Stylistic and thematic character- } \\
\text { istics of Nigerian painting are } \\
\text { well understood }\end{array}$ & 261 & 437 & 698 & 2.4 & 12.634 & 0.013 & $\begin{array}{c}\text { Difference not } \\
\text { Significant }\end{array}$ \\
\hline 9 & $\begin{array}{l}\text { Painting expressed in realism or } \\
\text { naturalism styles are clearer in } \\
\text { content and meaning }\end{array}$ & 347 & 530 & 877 & 3.1 & 3.849 & 0.427 & $\begin{array}{c}\text { Difference not } \\
\text { Significant }\end{array}$ \\
\hline 10 & $\begin{array}{l}\text { Student / apprentices are ade- } \\
\text { quately exposed to the relevance } \\
\text { of communication in painting. }\end{array}$ & 286 & 479 & 765 & 2.7 & 3.317 & 0.506 & $\begin{array}{l}\text { Difference not } \\
\text { Significant }\end{array}$ \\
\hline 11 & $\begin{array}{l}\text { All Nigerian painting should } \\
\text { have descriptive details or title }\end{array}$ & 358 & 534 & 892 & 3.1 & 41.049 & 0.000 & $\begin{array}{l}\text { Difference not } \\
\text { Significant }\end{array}$ \\
\hline 12 & $\begin{array}{l}\text { The apprenticeship method of } \\
\text { training in art appears to be lost }\end{array}$ & 235 & 434 & 669 & 2.3 & 6.014 & 0.198 & $\begin{array}{l}\text { Difference not } \\
\text { Significant }\end{array}$ \\
\hline 13 & $\begin{array}{l}\text { The individuality and identity } \\
\text { issue in contemporary Nigerian } \\
\text { painting seems to bring clarity of } \\
\text { expression. }\end{array}$ & 296 & 462 & 758 & 2.6 & 5.516 & 0.238 & $\begin{array}{c}\text { Difference not } \\
\text { Significant }\end{array}$ \\
\hline 14 & $\begin{array}{l}\text { Paintingconstitutes a veritable } \\
\text { bridge between the inner and } \\
\text { outer worlds of man }\end{array}$ & 348 & 507 & 855 & 3.0 & 9.401 & 0.052 & $\begin{array}{c}\text { Difference not } \\
\text { Significant }\end{array}$ \\
\hline 15 & $\begin{array}{l}\text { A picture has a better and last- } \\
\text { ing impression in the mind of } \\
\text { the viewer than verbal aids. }\end{array}$ & 366 & 573 & 939 & 3.3 & 3.187 & 0.527 & $\begin{array}{c}\text { Difference not } \\
\text { Significant }\end{array}$ \\
\hline 16 & $\begin{array}{l}\text { Everybody is quite aware of } \\
\text { painting as an aspect of art. }\end{array}$ & 332 & 560 & 892 & 3.1 & 1.296 & 0.862 & $\begin{array}{l}\text { Difference not } \\
\text { Significant }\end{array}$ \\
\hline 17 & $\begin{array}{l}\text { People have the understanding } \\
\text { of painting in terms of forms } \\
\text { and colours as the primary } \\
\text { content. }\end{array}$ & 307 & 504 & 811 & 2.8 & 1.661 & 0.798 & $\begin{array}{c}\text { Difference not } \\
\text { Significant }\end{array}$ \\
\hline 18 & $\begin{array}{l}\text { Paintings expressed in collage, } \\
\text { mixed media abstraction, mono- } \\
\text { media styles, realistic styles are } \\
\text { well known to everybody. }\end{array}$ & 188 & 385 & 573 & 2.0 & 12.885 & 0.012 & $\begin{array}{c}\text { Difference not } \\
\text { Significant }\end{array}$ \\
\hline
\end{tabular}


Table 5. Distribution of Respondents by Age Groups

\begin{tabular}{|c|c|c|c|c|c|c|c|c|c|c|}
\hline $\mathrm{S} / \mathrm{N}$ & VARIABLES & $\begin{array}{c}18- \\
25 y r s\end{array}$ & $\begin{array}{c}26- \\
40 y r s\end{array}$ & $\begin{array}{c}40- \\
60 \mathrm{yrs}\end{array}$ & $>60 y r s$ & $\begin{array}{l}\text { To- } \\
\text { Tal }\end{array}$ & $\begin{array}{c}\text { Av- } \\
\text { erage }\end{array}$ & $X^{2}$ & $\begin{array}{l}\text { P-VAL- } \\
\text { UE }\end{array}$ & REMARK \\
\hline 1 & $\begin{array}{l}\text { All Nigerian paintings are } \\
\text { effective in terms of commu- } \\
\text { nication }\end{array}$ & 401 & 391 & 43 & 03 & 838 & 2.9 & 11.903 & 0.453 & $\begin{array}{l}\text { Difference } \\
\text { not signifi- } \\
\quad \text { cant }\end{array}$ \\
\hline 2 & $\begin{array}{l}\text { Painting as an aspect of non- } \\
\text { verbal communication is one } \\
\text { of the best forms of commu- } \\
\text { nication }\end{array}$ & 395 & 413 & 55 & 03 & 866 & 3.0 & 13.492 & 0.334 & $\begin{array}{l}\text { Difference } \\
\text { not signifi- } \\
\quad \text { cant }\end{array}$ \\
\hline 3 & $\begin{array}{l}\text { Nigerian are strongly aware } \\
\text { of colour symbolism as } \\
\text { means of communications }\end{array}$ & 348 & 323 & 38 & 03 & 712 & 2.5 & 34.534 & 0.001 & Significant \\
\hline 4 & $\begin{array}{l}\text { Audience in Nigeria are all } \\
\text { aware of and look at painting }\end{array}$ & 305 & 323 & 37 & 04 & 669 & 2.3 & 7.704 & 0.808 & $\begin{array}{l}\text { Difference } \\
\text { not signifi- } \\
\quad \text { cant }\end{array}$ \\
\hline 5 & $\begin{array}{l}\text { All artistic spectators can de- } \\
\text { code the content of painting }\end{array}$ & 322 & 358 & 30 & 02 & 612 & 2.1 & 28.004 & 0.006 & Significant \\
\hline 6 & $\begin{array}{l}\text { Communication is one of } \\
\text { the functions of Nigerian } \\
\text { painting }\end{array}$ & 394 & 423 & 59 & 04 & 880 & 3.1 & 10.606 & 0.563 & $\begin{array}{l}\text { Difference } \\
\text { not signifi- } \\
\text { cant }\end{array}$ \\
\hline 7 & $\begin{array}{l}\text { Paintings that are produced } \\
\text { from 1970till date are expres- } \\
\text { sive }\end{array}$ & 350 & 360 & 55 & 02 & 767 & 2.7 & 14.088 & 0.295 & $\begin{array}{l}\text { Difference } \\
\text { not signifi- } \\
\quad \text { cant }\end{array}$ \\
\hline 8 & $\begin{array}{l}\text { Stylistic and thematic charac- } \\
\text { teristics of Nigerian painting } \\
\text { are well understood }\end{array}$ & 350 & 360 & 55 & 02 & 767 & 2.7 & 28.190 & 0.005 & Significant \\
\hline 9 & $\begin{array}{l}\text { Painting expressed in re- } \\
\text { alistic or naturalism styles } \\
\text { are clearer in content and } \\
\text { meaning }\end{array}$ & 333 & 316 & 41 & 03 & 693 & 2.4 & 9.633 & 0.648 & $\begin{array}{l}\text { Difference } \\
\text { not signifi- } \\
\text { cant }\end{array}$ \\
\hline 10 & $\begin{array}{l}\text { Student / apprentices are } \\
\text { adequately exposed to the } \\
\text { relevance of communication } \\
\text { in painting. }\end{array}$ & 396 & 413 & 54 & 03 & 866 & 3.0 & 55.753 & 0.000 & Significant \\
\hline 11 & $\begin{array}{l}\text { All Nigerian painting should } \\
\text { have descriptive details or } \\
\text { title }\end{array}$ & 360 & 358 & 37 & 0 & 755 & 2.6 & 25.650 & 0.012 & Significant \\
\hline 12 & $\begin{array}{l}\text { The apprenticeship method } \\
\text { of training in art appears to } \\
\text { be lost }\end{array}$ & 400 & 432 & 48 & 02 & 882 & 3.0 & 31.675 & 0.002 & Significant \\
\hline 13 & $\begin{array}{l}\text { The individuality and iden- } \\
\text { tity issue in contemporary } \\
\text { Nigerian painting seems to } \\
\text { bring clarity of expression. }\end{array}$ & 342 & 286 & 32 & 02 & 662 & 2.3 & 10.044 & 0.612 & $\begin{array}{l}\text { Difference } \\
\text { not signifi- } \\
\quad \text { cant }\end{array}$ \\
\hline 14 & $\begin{array}{l}\text { Paintingconstitutes a verita- } \\
\text { ble bridge between the inner } \\
\text { and outer worlds of man }\end{array}$ & 341 & 359 & 43 & 03 & 746 & 2.6 & 10.533 & 0.569 & $\begin{array}{l}\text { Difference } \\
\text { not signifi- } \\
\quad \text { cant }\end{array}$ \\
\hline 15 & $\begin{array}{l}\text { A picture has a better and } \\
\text { lasting impression in the } \\
\text { mind of the viewer than } \\
\text { verbal aids. }\end{array}$ & 369 & 426 & 52 & 04 & 851 & 3.0 & 14.325 & 0.280 & Significant \\
\hline 16 & $\begin{array}{l}\text { Everybody is quite aware of } \\
\text { painting as an aspect of art. }\end{array}$ & 412 & 458 & 54 & 04 & 928 & 3.2 & 18.881 & 0.091 & $\begin{array}{l}\text { Difference } \\
\text { not signifi- } \\
\text { cant }\end{array}$ \\
\hline
\end{tabular}




\begin{tabular}{|c|c|c|c|c|c|c|c|c|c|c|}
\hline 17 & $\begin{array}{l}\text { People have the understand- } \\
\text { ing of painting in terms of } \\
\text { forms and colours as the } \\
\text { primary content. }\end{array}$ & 418 & 413 & 47 & 04 & 882 & 3.1 & 19.939 & 0.068 & $\begin{array}{l}\text { Difference } \\
\text { not signifi- } \\
\text { cant }\end{array}$ \\
\hline 18 & $\begin{array}{l}\text { Paintings expressed in } \\
\text { college, mixed media } \\
\text { abstraction, mono-media } \\
\text { styles,realistic styles are well } \\
\text { known to everybody. }\end{array}$ & 384 & 347 & 40 & 4 & 775 & 2.7 & 47.284 & 0.000 & Significant \\
\hline
\end{tabular}

Table 6. Distribution of Respondents by degree obtained

\begin{tabular}{|c|c|c|c|c|c|c|c|c|c|c|c|c|c|}
\hline $\mathrm{S} / \mathrm{N}$ & Variables & Ph.D & $\begin{array}{c}\text { Mas- } \\
\text { ter }\end{array}$ & $\begin{array}{l}\text { Bach- } \\
\text { elor }\end{array}$ & HND & NCE & $\begin{array}{l}\mathrm{O} \\
\mathrm{N} \\
\mathrm{D}\end{array}$ & $\mathrm{OL}$ & $\begin{array}{l}\text { To- } \\
\text { tal }\end{array}$ & $\begin{array}{l}\text { Av- } \\
\text { er- } \\
\text { age }\end{array}$ & $X^{2}$ & $\begin{array}{l}\text { P- } \\
\text { Val- } \\
\text { ue }\end{array}$ & Remark \\
\hline 1 & $\begin{array}{l}\text { All Nigerian paintings } \\
\text { are effective in terms of } \\
\text { communication }\end{array}$ & 07 & 41 & 592 & 73 & 05 & 46 & 82 & 846 & 2.9 & 45.180 & 0.006 & $\begin{array}{l}\text { Signifi- } \\
\text { cant }\end{array}$ \\
\hline 2 & $\begin{array}{l}\text { Painting as an aspect of } \\
\text { non-verbal communica- } \\
\text { tion is one of the best } \\
\text { forms of communica- } \\
\text { tion }\end{array}$ & 14 & 48 & 601 & 77 & 06 & 41 & 87 & 874 & 3.0 & 34.561 & 0.075 & $\begin{array}{l}\text { Differ- } \\
\text { ence } \\
\text { not } \\
\text { signifi- } \\
\text { cant }\end{array}$ \\
\hline 3 & $\begin{array}{l}\text { Nigerian are strongly } \\
\text { aware of colour sym- } \\
\text { bolism as means of } \\
\text { communications }\end{array}$ & 12 & 45 & 493 & 63 & 03 & 34 & 78 & 728 & 2.5 & 22.333 & 0.559 & $\begin{array}{l}\text { Differ- } \\
\text { ence } \\
\text { not } \\
\text { signifi- } \\
\text { cant }\end{array}$ \\
\hline 4 & $\begin{array}{c}\text { Audience in Nigeria are } \\
\text { all aware of andlook at } \\
\text { painting }\end{array}$ & 13 & 31 & 459 & 71 & 07 & 30 & 67 & 678 & 2.4 & 28.188 & 0.252 & $\begin{array}{l}\text { Differ- } \\
\text { ence } \\
\text { not } \\
\text { signifi- } \\
\text { cant }\end{array}$ \\
\hline 5 & $\begin{array}{l}\text { All artistic spectators } \\
\text { can decode thecontent } \\
\text { of painting }\end{array}$ & 09 & 22 & 424 & 41 & 03 & 33 & 80 & 612 & 2.1 & 54.220 & 0.000 & $\begin{array}{c}\text { Signifi- } \\
\text { cant }\end{array}$ \\
\hline 6 & $\begin{array}{l}\text { Communication is } \\
\text { one of the functions of } \\
\text { Nigerian painting }\end{array}$ & 17 & 55 & 640 & 81 & 06 & 44 & 81 & 924 & 3.2 & 30.558 & 0.167 & $\begin{array}{l}\text { Differ- } \\
\text { ence } \\
\text { not } \\
\text { signifi- } \\
\text { cant }\end{array}$ \\
\hline 7 & $\begin{array}{l}\text { Paintings that are } \\
\text { produced from } 1970 \text { till } \\
\text { date are expressive }\end{array}$ & 14 & 43 & 531 & 71 & 08 & 41 & 72 & 780 & 2.7 & 41.147 & 0.016 & $\begin{array}{l}\text { Signifi- } \\
\text { cant }\end{array}$ \\
\hline 8 & $\begin{array}{l}\text { Stylistic and thematic } \\
\text { characteristics of Nige- } \\
\text { rian painting are well } \\
\text { understood }\end{array}$ & 09 & 33 & 481 & 64 & 02 & 36 & 66 & 692 & 2.4 & 39.062 & 0.027 & $\begin{array}{c}\text { Signifi- } \\
\text { cant }\end{array}$ \\
\hline 9 & $\begin{array}{l}\text { Painting done in real- } \\
\text { istic or natural is styles } \\
\text { are clearer in content } \\
\text { and meaning }\end{array}$ & 07 & 46 & 598 & 82 & 07 & 36 & 91 & 877 & 3.0 & 21.570 & 0.605 & $\begin{array}{l}\text { Differ- } \\
\text { ence } \\
\text { not } \\
\text { signifi- } \\
\text { cant }\end{array}$ \\
\hline 10 & $\begin{array}{l}\text { Student / apprentices } \\
\text { are adequately exposed } \\
\text { to the relevance of com- } \\
\text { munication in painting. }\end{array}$ & 11 & 34 & 547 & 64 & 03 & 34 & 68 & 761 & 2.7 & 40.178 & 0.020 & $\begin{array}{c}\text { Signifi- } \\
\text { cant }\end{array}$ \\
\hline
\end{tabular}




\begin{tabular}{|c|c|c|c|c|c|c|c|c|c|c|c|c|c|}
\hline 11 & $\begin{array}{l}\text { All Nigerian painting } \\
\text { should have descriptive } \\
\text { details or title }\end{array}$ & 15 & 41 & 613 & 77 & 04 & 43 & 96 & 889 & 3.1 & 24.776 & 0.418 & $\begin{array}{l}\text { Differ- } \\
\text { ence } \\
\text { not } \\
\text { signifi- } \\
\text { cant }\end{array}$ \\
\hline 12 & $\begin{array}{l}\text { The apprenticeship } \\
\text { method of training in } \\
\text { art appears to be lost }\end{array}$ & 08 & 34 & 456 & 51 & 04 & 36 & 76 & 665 & 2.3 & 48.908 & 0.002 & $\begin{array}{l}\text { Signifi- } \\
\text { cant }\end{array}$ \\
\hline 13 & $\begin{array}{l}\text { The individuality } \\
\text { and identity issue in } \\
\text { contemporaryNigerian } \\
\text { painting seems to bring } \\
\text { clarity of expression. }\end{array}$ & 14 & 39 & 525 & 73 & 03 & 32 & 72 & 758 & 2.6 & 33.884 & 0.087 & $\begin{array}{l}\text { Differ- } \\
\text { ence } \\
\text { not } \\
\text { signifi- } \\
\text { cant }\end{array}$ \\
\hline 14 & $\begin{array}{l}\text { Paintingconstitutes } \\
\text { a veritable bridgebe- } \\
\text { tween the inner and } \\
\text { outer worlds ofman }\end{array}$ & 16 & 47 & 585 & 77 & 03 & 39 & 90 & 857 & 3.0 & 26.987 & 0.305 & $\begin{array}{l}\text { Differ- } \\
\text { ence } \\
\text { not } \\
\text { signifi- } \\
\text { cant }\end{array}$ \\
\hline 15 & $\begin{array}{l}\text { A picture has a better } \\
\text { and lasting impres- } \\
\text { sion in the mind of } \\
\text { the viewer than verbal } \\
\text { aids. }\end{array}$ & 22 & 51 & 648 & 80 & 03 & 44 & 87 & 935 & 3.2 & 18.956 & 0.754 & $\begin{array}{l}\text { Differ- } \\
\text { ence } \\
\text { not } \\
\text { signifi- } \\
\text { cant }\end{array}$ \\
\hline 16 & $\begin{array}{c}\text { Everybody is quite } \\
\text { aware of painting as an } \\
\text { aspect of art. }\end{array}$ & 19 & 42 & 613 & 74 & 04 & 42 & 94 & 888 & 3.1 & 22.685 & 0.538 & $\begin{array}{l}\text { Differ- } \\
\text { ence } \\
\text { not } \\
\text { signifi- } \\
\text { cant }\end{array}$ \\
\hline 17 & $\begin{array}{l}\text { People have to un- } \\
\text { derstand of painting } \\
\text { in terms offorms and } \\
\text { colours as the } \\
\text { primary content. }\end{array}$ & 18 & 36 & 561 & 59 & 03 & 36 & 95 & 808 & 2.8 & 38.421 & 0.031 & $\begin{array}{l}\text { Signifi- } \\
\text { cant }\end{array}$ \\
\hline 18 & $\begin{array}{l}\text { Paintings done in } \\
\text { college, mixed media } \\
\text { abstraction, mono- } \\
\text { media styles, realistic } \\
\text { styles are well known } \\
\text { to everybody. }\end{array}$ & 07 & 22 & 418 & 36 & 0 & 21 & 65 & 569 & 2.0 & 37.791 & 0.036 & $\begin{array}{l}\text { Signifi- } \\
\text { cant }\end{array}$ \\
\hline
\end{tabular}

firmatively than other educational groups, as regards effectiveness of communication through painting. This is followed by the graduates of polytechnics and amazingly followed by secondary school leavers. The reason for this pattern may be the numerical composition of the respondents which had favoured the groups in the listed order. Another reason may be the difference in art inclination (professional/art lover dichotomy) even among the educational groups. It is important to state that though there are relative differences in the responses of the different educational groups, for some four variables, in particular, the differences in the responses are not statistically significant. Most of the respondents support painting as an effective non-verbal communication. The responses when compared among the educational groups are significantly different from one another. This implies that while some spoke in support, others responded against. The reason advanced for the difference in the responses in this study is their level of education. In other words, advancement in art education influences people in the understanding of the works of painting. In particular, seeing painting as one of the best forms of communication, in understanding the 
stylistic and the thematic characteristics of contemporary paintings, seeing painting as a connector of the inner and outer world of a man and the understanding of paintings in terms of forms and colours are functions of educational level.

Gender factor was also considered to determine effective communication in painting. The chi-square and P-values of the test of difference as associated with the gender rating are presented in Table 3 . What you see stays more in your mind than what is being described through verbal communication. This could be because title given to a painting serves as a guide or tip to the understanding of the content of a painting. However, some titles often go contrary to the visual message of some painting. Painting as an aspect of non-verbal communication is one of the best forms of communication. It also receives a certain level of agreement from both respondents. The possible reasons for divergent opinions might be because the two categories of respondents are not equal in population size. Art lovers are greater in number than professional artists that responded to the variable. Also, it could be due to the fact that art generally is a universal language of communication which should be understood by everybody irrespective of their inclinations. Another variable that received divergent views from the two categories of respondents is that all artistic spectators can decode the content of painting in Nigeria. Those that spoke against this variable might be considering the post-modernism characteristics of painting which enable each artist to go individualistic in style rendition which often times create difficulty in decoding the content of such painting. Different age groups were also used to measure the variables as regards the effective communication in painting as been shown in Table 5. This shows the respondents' views about different aspects of painting, and the test of variations across the age groups. The relative differences based on the degree obtained are statistically significant in about six variables (1), (5), (8), (10), (12) (17), in particular. Some of the respondents spoke in support of these variables while some stand against it. This could be as a result of different exposures of different levels of the degrees obtained.

\section{CONCLUSION}

This paper has shown that audience perception of painting in Nigeria symbolizes the intended message that codifies meaning and expression of emotions of an art piece. It observes that painting is a means to convey a wide range of stories, emotions, and feelings. Painting in Nigeria is a nonverbal means of expressing an idea creatively through colour, light, size, depth, and textual gradients. Effective Communication in visual studies and painting, in particular, depends on the understanding of the message being passed through the adequate use of style, media and subject matter between the Artist and the audience.

\section{RFEREENCES}

Adeniji, A. A. (2004). Discourse Analysis of Convocation Speeches of Two Selected Nigerian Universities. Unpublished M.A. dissertation. Department of English, University of Ibadan.

Babajide, A. (2000). Studies in English Language; Ibadan: Enicrownfit Publishers.

Barber, C. (1964). The Story of Language, London: Pan Books Ltd.

Cleaver, D. (1966). Art: An Introduction, Harcourt Brace, and World Inc.

Davidson, M. (2003). How to Draw and Paint Texture. Quarto Publishing Ltd

Folorunso, F. C. (2001). Visual Artand Communication Technology:Reshaping Nigeria's Development in the New Millennium. Jindest, 2(2), 25-32.

Harrigan, C. (2007). Abstract and Colour Techniques in Painting. London: Anova Books Company Ltd.

Hill, E. (1966). The Language of Drawing. Englewood cliff: N.J. Prentice.

Getlein, M. (2002). Living with Art. New York. McGraw-Hill Higher Educa- 
tion.

Igboanugo, P. (1976). Home to Christopher Okigbo, an Exhibition by Obiora Udechukwu. Nigeria Magazine, No. 120. pp. 22-28.

Kalilu, R. O. R (1999). Fundamentals of Drawing. Ogbomoso: Department of Fine and Applied Arts, Lautech.

Lamidi T. (2000). Language, varieties and context' in Babajide A.O. (ed) studies in English Language. Ibadan: Enicrownfit Publishers.

Odumosu, T. (1999). Location and regional setting of Lagos State. In Balogun Y., Odumosu T., Ojo K. (ed). Lagos State in maps. Ibadan: Rex Charles Publication and Connel Publications.
Oladosu, I. (2003). Review of Basic Concepts in Communication. Ogbomoso: New Age Publications.

Oyewo, Y. (2000). Human Communication: An Introduction in Babajide A.O (ed) Studies. in English language; Ibadan: Enicrownfit Publishers.

Tracii, H. (2010). What is verbal communication. Retrieved from http://www. Livestrong.com

Woods, H. T. (2011). The Factor of Drawing in Visual Communication in Nigeria, (1998-2008). An Unpublished M.Tech. Thesis in the Department of Fine and Applied Arts, LAUTECH, Ogbomoso. 